Research Journal of Biological Sciences 5 (8): 556-560, 2010

ISSN: $1815-8846$

(C) Medwell Journals, 2010

\title{
Composition and Abundance of Macrobenthos in Majidun River, Ikorordu Lagos State, Nigeria
}

\author{
I.K. Esenowo and A.A.A. Ugwumba \\ Department of Zoology, University of Ibadan, Ibadan, Oyo State, Nigeria
}

\begin{abstract}
A study on the composition and abundance of macrobenthos of Majidun river, Ikorodu, Lagos state was carried out from June, 2008 to May 2009 at 6 sampling stations along the river from its source to the mouth. The river is a multipurpose resource for artisanal fishing, transportation, sand mining and domestic uses. A total of 10,799 individuals of macrobenthos belonging to 18 genera in two Phyla, Mollusca and Anthropoda were recorded from the 6 sampling stations. Mollusca were represented by Bivalvia and Gastropoda, the most common species were the gastropods: Pachymelania aurita, P. fusca, P. fusca var. quadriserlata, Tympanotomus fuscatus var. radula, T. fuscatus fuscatus and Melanoides tuberculata. Arthropoda consisted mainly of caddis fly larva, Phryganea sp., the crabs: Sesarma huzardii, Cardisoma armatum and Callinectes latimanus and the prawn: Macrobrachium marobrachion. T. fuscatus var. radula was the most abundant species accounting for $20.17 \%$, closely followed by $P$. aurita $19.58 \%$ while the least abundant, Phryganea sp., accounted for $<0.1 \%$ of the total number of macrobenthos. Shannon-wiener diversity index indicated a maximum of 0.97 in mid river station (surrounded by mangrove trees) compared to the stations at the source of the river $(0.88)$ and its mouth (0.87) where it flows into Lagos Lagoon. Macrobenthos abundance and diversity levels were significantly low.
\end{abstract}

Key words: Macrobenthos, composition, diversity, abundance, ikorodu, Majidun river

\section{INTRODUCTION}

Macrobenthos play an important role in aquatic community which includes mineralization, mixing of sediments and flux of oxygen into sediment, cycling of organic matter and assessing the quality of inland water (George et al., 2009). The distribution of macrobenthos fauna are determined by a number of factors such as physical nature of the substratum, depth, nutritive content, degree of stability and oxygen content of the water body. Benthic microinvertebrates are threatened by changes in its habitat which are associated with pollution, erosion and siltation (Lydeard et al., 2004).

In assessing the health of aquatic environment, bioassessment has become a reliable method for measuring human influence on aquatic ecosystems, complementing traditional physical and chemical methods. The presence or absence of benthic macroinvertebrates has been shown to be a good indicator of both chronic and episodic impact of human disturbance to river condition and other aquatic environment (Rosenberg and Resh, 1993).

Diaz et al. (2004) described benthic infauna as opportunistic species adapted to a dynamic salinity regime and variable physical conditions. Benthic species composition, abundance, biomass and distribution patterns are to a large extent determined by a mixture of interacting variable of physico-chemical parameters like temperature regime, dissolved oxygen concentration, salinity and biochemical oxygen demand (Dillon, 2000; Edokpayi et al., 2000; Celik, 2002; Egborge et al., 2003; Ikomi et al., 2005).

Majidun river is one of the important rivers in Lagos state found in the Western part of Nigeria. It is noted for artisanal fisheries and transportation. Macrobenthos constitute the food for fishes hence, it is important to have reliable information on species composition. Several researches exist on the diversity and abundance of species composition for other freshwater system located in Lagos state such as the Lagos Lagoon (Akpata et al., 1993; Brown and Ajao, 2004), Lekki Lagoon (Awosika and Dublin-Green, 1994) and Port Novo Creek (Chukwu and Nwankwo, 2003). This study constitutes the 1 st record of an investigation into the diversity and abundance of macrobenthos in Majidun river.

\section{MATERIALS AND METHODS}

Study area: Majidun river is located in Ikorodu, Lagos state on the Southwestern part of Nigeria coastline within

Corresponding Author: I.K. Esenowo, Department of Zoology, University of Ibadan, Ibadan, Oyo State, Nigeria 

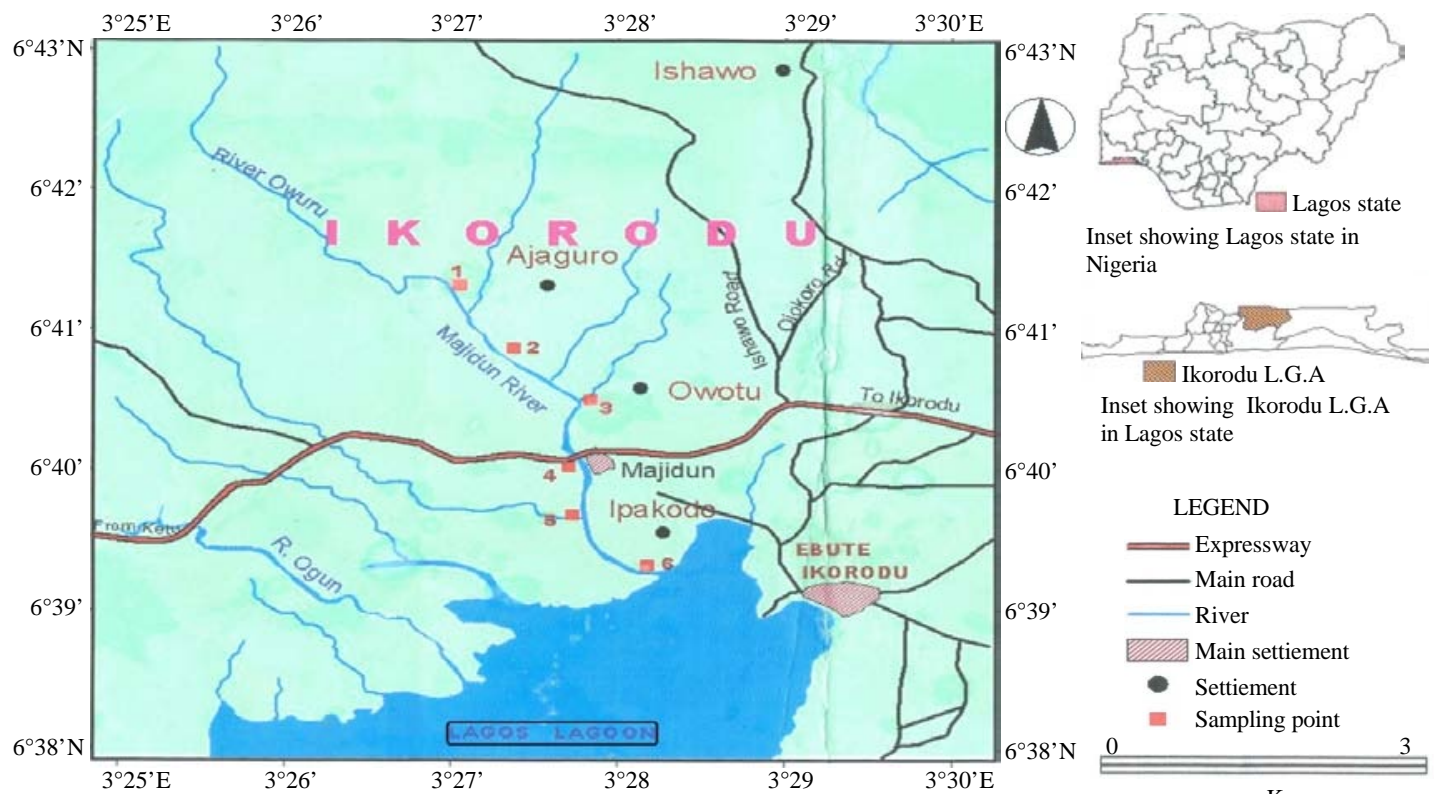

in Lagos state

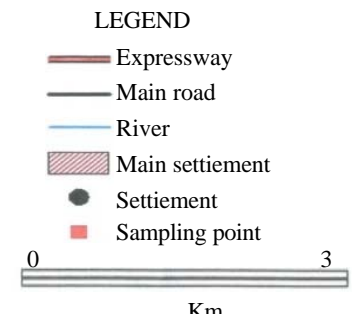

Fig. 1: Map of Ikorodu showing Majidun river and sampling stations (1-6)

longitude $3.22^{\circ}$ and $3.29^{\circ} \mathrm{E}$ and latitude $6.39^{\circ}$ and $6.41^{\circ} \mathrm{N}$ (Fig. 1). It has a catchment area of $2.9 \mathrm{~km}^{2}$ with its major source from River Owuru and flows into Lagos Lagoon at Ipakodo from where it receives tidal waters from the Lagoon. The river is a multipurpose resource for artisanal fishing, sand mining, transportation and for domestic uses. Sandy beaches are seen in stations 4-6 of the river where there is sand mining activities while stations 1-3 are fringed with tidal mud flats and mangrove swamps in which plants such as Rhizophora racemosa, Avicenia nitida and Echiorna crassepes are to be found.

At each sampling station, three replicate samples of macrobenthos were collected monthly using $0.1 \mathrm{~m}^{2}$ Van veen Grab from June 2008 to May 2009. The sediment collected were poured into polythene bags, labeled and brought to the laboratory for examination.

In the laboratory, each sediment sample was washed through three sets of sieves, 1 st $2 \mathrm{~mm}$ then $1 \mathrm{~mm}$ and finally $0.5 \mathrm{~mm}$ mesh size, sieve to collect the macrobenthos in them. The retained macrobenthos were poured into a white enamel tray and stained with Rose Benger solution (Holme and McIntyre, 1984). They were sorted using forceps, identified using Macan (1959), Pennak (1978), Edmunds (1978) and WHO (1978) and counted. Macrobenthos diversity was estimated using the Shannon-weiner index of diversity $(\mathrm{H})$ (Shannon and Weaver, 1963) and Equitability index or Evenness (J) (Lloyd and Ghellardi, 1964).

\section{RESULTS}

The composition, abundance and distribution of the macrobenthos in the study area are shown in Table 1. A

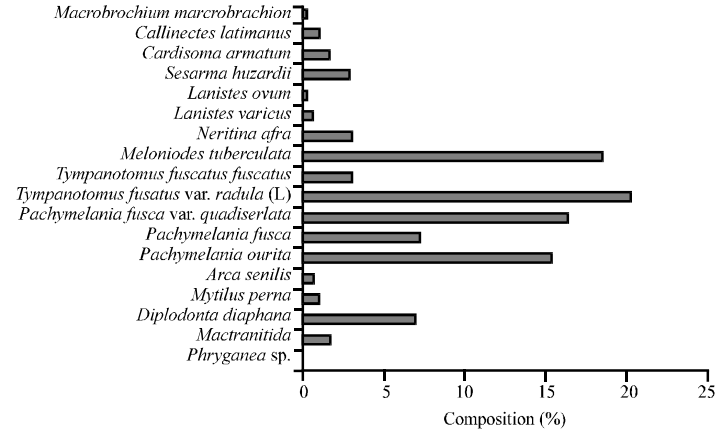

Fig. 2: Percentage (number) of macrobrnthos in Majidun river

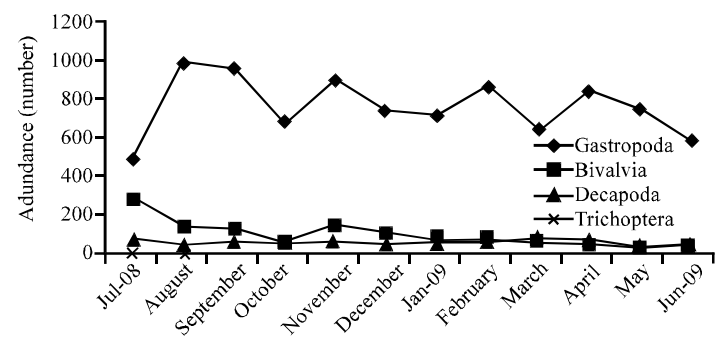

Fig. 3: Monthly relative abundance of marcrobenthos in Majidun river (July 2008 to June 2009)

total of 18 Macrobenthos genera belonging to two phyla Mollusca and Arthropoda were recorded. Phylum Mollusca was represented by gastropoda and bivalvia while Arthropoda were mainly decapods and trichoptera. The gastropoda, Tympanotomus fuscatus var. radula (L) was the most dominant species accounting for about 
Res. J. Biol. Sci., 5 (8): 556-560, 2010

\begin{tabular}{|c|c|c|c|c|c|c|c|c|c|c|c|c|}
\hline \multirow[b]{2}{*}{ Macrobenthos taxa } & \multicolumn{2}{|c|}{ Station 1} & \multicolumn{2}{|c|}{ Station 2} & \multicolumn{2}{|c|}{ Station 3} & \multicolumn{2}{|c|}{ Station 4} & \multicolumn{2}{|c|}{ Station 5} & \multicolumn{2}{|c|}{ Station 6} \\
\hline & No & $(\%)$ & No & $(\%)$ & No & $(\%)$ & No & $(\%)$ & No & $(\%)$ & No & $(\%)$ \\
\hline \multicolumn{13}{|l|}{ Gastropoda } \\
\hline Pachymelonia aurita & 13 & 1.5 & 3 & 0.3 & 65 & 4.1 & 610 & 21.1 & 748 & 22.8 & 210 & 19.6 \\
\hline Pachymelania fusca & 10 & 1.2 & 2 & 0.2 & 13 & 0.8 & 330 & 11.4 & 341 & 10.4 & 82 & 7.6 \\
\hline Pachymelania fusca var. quadriserlata & 122 & 14.4 & 296 & 26.4 & 377 & 23.7 & 388 & 13.4 & 434 & 13.2 & 140 & 13.1 \\
\hline Tympanotomus fuscatus var. radula $(\mathrm{L})$ & 281 & 33.1 & 251 & 22.4 & 377 & 23.7 & 547 & 19.0 & 459 & 14.0 & 264 & 24.6 \\
\hline Tympanotomus fiscatus fuscatus & & & & & 8 & 0.5 & 112 & 3.9 & 148 & 4.5 & 49 & 4.6 \\
\hline Melanoides tuberculata & 158 & 18.6 & 264 & 23.6 & 432 & 27.1 & 390 & 13.5 & 571 & 17.4 & 173 & 16.1 \\
\hline Neritina afra & 30 & 3.5 & 32 & 2.9 & 49 & 3.1 & 64 & 2.2 & 99 & 3.0 & 50 & 4.7 \\
\hline Lanistes varicus & 34 & 4.0 & 18 & 1.6 & 5 & 0.3 & 3 & 0.1 & 1 & 0.1 & $*$ & $*$ \\
\hline Lanistes ovum & 14 & 1.6 & 5 & 0.4 & 4 & 0.3 & 4 & 0.1 & 1 & 0.1 & & \\
\hline \multicolumn{13}{|l|}{ Bivalvia } \\
\hline Mactra nitida & 17 & 2 & 17 & 1.5 & 21 & 1.3 & 55 & 1.9 & 49 & 1.5 & 16 & 1.5 \\
\hline Diplodonta dicphana & 14 & 1.6 & 100 & 8.9 & 140 & 8.8 & 106 & 3.7 & 299 & 9.1 & 83 & 7.7 \\
\hline Mytilus perna & * & $*$ & 4 & 0.4 & 21 & 1.3 & 59 & 2.0 & 21 & 0.6 & & \\
\hline Arca senilis & * & * & $*$ & $*$ & 4 & 0.3 & 37 & 1.3 & 27 & 0.8 & 3 & 0.3 \\
\hline \multicolumn{13}{|l|}{ Decapoda } \\
\hline Sesarma angolense & 90 & 10.6 & 60 & 5.4 & 15 & 0.9 & 75 & 2.6 & 66 & 2.0 & 2 & 0.2 \\
\hline Pachygropsus transverses & 52 & 6.1 & 11 & 1.0 & 57 & 3.6 & 51 & 1.8 & 4 & 0.1 & * & $*$ \\
\hline Callinectes amnicola & 3 & 0.4 & 41 & 3.7 & 5 & 0.3 & 52 & 1.8 & 9 & 0.3 & * & $*$ \\
\hline Macrobrachium macrobrachion & 11 & 1.3 & 15 & 1.3 & * & $*$ & 2 & 0.1 & * & $*$ & $*$ & $*$ \\
\hline \multicolumn{13}{|l|}{ Trichoptera } \\
\hline Phryganea sp. (Caddis fly larva) & 1 & 0.1 & 1 & 0.1 & 1 & 0.1 & 1 & 0.1 & * & $*$ & $*$ & $*$ \\
\hline$S=$ & 15 & - & 16 & & 17 & & 18 & & 16 & - & 11 & - \\
\hline $\mathrm{N}=$ & 850 & - & 1,120 & & 1,594 & & 2,886 & & 3,277 & - & 1,072 & \\
\hline
\end{tabular}

$\mathrm{S}:$ Number of Species; $\mathrm{N}$ : Total number of individuals *: Benthic macroinvertebrates were not encountered

Table 2: Diversity of macrobenthos in the sampling stations of Majidun river

\begin{tabular}{lcccccc}
\hline Factors & Station 1 (source of river) & Station 2 & Station 3 & Station 4 & Station 5 & Station 6 (mouth of river) \\
\hline No. of individuals $(\mathrm{N})$ & 850 & 1120 & 1594 & 2886 & 3277 & 1072 \\
No. of Species (S) & 15 & 16 & 17 & 18 & 16 & 11 \\
Shannon-wiener diversity (H) & 0.880 & 0.839 & 0.825 & 0.971 & 0.923 & 0.866 \\
Eveness index (E) & 0.748 & 0.696 & 0.670 & 0.773 & 0.766 & 0.831 \\
\hline
\end{tabular}

$20.2 \%$, closely followed by Pachymelania aurita with $19.6 \%$ and the least, Phryganea sp. a trichoptera insect accounted for $<0.1 \%$ of the total number of macrobenthos (Fig. 2). Highest gastropods numbers were recorded in August (84.8\%) 2008 while the lowest were recorded in July (58.8\%) 2008. Trichoptera was only recorded in July and August 2008 and the abundance was $<1 \%$ of the total number. Bivalvia and Decapoda were relatively constant throughout the study period as shown in the (Fig. 3). The Shannon-wiener diversity index $(\mathrm{H})$ showed that the highest mean of 0.97 was recorded in station 4 , followed by station 5 with mean of 0.92 while the lowest mean value (0.83) was recorded in station 3. Evenness index (E) ranged from 0.670 in station $3-0.831$ in station 6 . The highest number of species (18) was recorded in station 4 while station 6 had the least number (11) species (Table 2).

\section{DISCUSSION}

The total number of 18 taxa reported in the present study is far less than those reported for rivers in humid tropics (Bishop, 1973; Edema et al., 2002; Adakole and Anunne, 2003) and these may be as a result of different environmental conditions such as water quality and movement, substrate instability, salinity regime and food availability just to mention a few (Dance and Hynes, 1980). However, the taxa richness of Majidun river is relatively higher than those of the research of Chukwu and Nwankwo (2003) who recorded 8 taxa in Port Novo Creek and Sikoki and Zabbey (2006) who recorded 14 taxa in Imo river. Gastropods and bivalves are relatively tolerant of physical and chemical variations in the environment and are usually present in a broad range of habitats. It is therefore, not surprising that they dominated the macrobenthos of the study area. Similar research by Ajao and Fagade (2002) also recorded gastropods as the dominant benthic fauna in Lagos Lagoon. The muddy nature of the substratum in the stations may have favours the growths of gastropods (Oyenakan, 1979). Egonmwan (2008) also reported gastropod to inhabit quite water where the substratum is muddy and rich in detritus.

The low abundance of the fresh water prawns, Macrobrachium macrobrachion and trichoptera (caddis fly larva) maybe an indication of relatively stressed environmental condition. Abowei et al. (2006) reported Macrobrachium prawns to be sensitive to deteriorated water quality condition while Emere and Nasiru (2007) reported trichopterans as pollution sensitive macroinvertebrates. 
The high Shannon-wiener diversity and eveness value in station 4 indicates high species richness. The low Shannon-wiener value with low eveness in station 3 indicates low species diversity. According to Mackie (1998), the longer a locality has been in the same condition the richer is its biotic community and the more stable it is. Therefore, low diversity in station 3 is an indication of stress in the environment as a result of various human activities while high diversity in station 4 is a reflection of stress-free and stable environment. Similar observations were made by Ajao and Fagade (1990) as to the imbalances of macroinvertebrate from the Western industrialized parts of Lagos Lagoon which received a complex mixture of domestic and industrial waste. The increase in macrobenthos abundance in the months of August to October could be attributed to the life history and population dynamics of the gastropods species that constituted the dominant macrobenthos taxa in this study. They are noted to be adapted to unstable water bodies and exploit brief period of favorable conditions, lasting only a few months to reproduce rapidly and build up dense population (Woolhouse and Chandiwana, 1990). The diversity and abundance of macrobenthos in Majidun river is low. Odum (1971) reported that diversity only tend to be low in physically disturbed ecosystem.

\section{CONCLUSION}

The intensity of sand mining and the uncontrolled discharged of domestic and industrial waste have pollution implications as they alter bottom conditions and destroy molluscs settlement areas (Cole, 1977). These may have probably resulted in the low diversity of this tropical river particularly in the 1 st 3 stations where many activities occur.

\section{REFERENCES}

Abowei, J.F., S.N. Deekae, M.E. Alison, C.C. Tawari and S.A. Ngodigha, 2006. A Review of Shrimp Fisheries in Nigeria. Pre-Joe Publisher, Port Harcourt, Nigeria, pp: 10 .

Adakole, J.A. and P.A. Anunne, 2003. Benthic macroinvertebrates as indicators of environmental quality of an urban stream in Zaria, Northern Nigeria. J. Aqua. Sci., 18: 85-92.

Ajao, E.A. and S.O. Fagade, 1990. A study of sediment communities in Lagos Lagoon, Nigeria. J. Oil Chem. Pollut., 7: 85-117.

Ajao, E.A. and S.O. Fagade, 2002. The benthic Macroinfauna of Lagos Lagoon. Zoologist, 1: 1-5.
Akpata, T.V.I., J.A. Oyenekan and D.I. Nwankwo, 1993. Impacts of organic pollution on the bacterial, plankton and benthic populations of Lagos Lagoon, Nigeria. Int. J. Ecol. Environ. Sci., 19: 73-82.

Awosika, L.F. and C.O. Dublin-Green, 1994. Sand mining in the Lagos and Lekki lagoons and strategies for effective management. J. Min. Geol., 30: 137-139.

Bishop, J.E., 1973. Limnology of a Small Malayan River Sungai Gombak. Dr. W. Junk, Hague, PP: 485.

Brown, C.A. and E.A. Ajao, 2004. Effects of topographic modification on the composition and abundance of macrofauna in Southern Lagos lagoon. West Afr. J. Applied Ecol., 5: 41-50.

Celik, K., 2002. Community structure of macrobenthos of a southeast texa sand-pit lake related to water temperature, $\mathrm{pH}$ and Dissolved oxygen concentration. Turk. J. Zool., 26: 333-339.

Chukwu, L.O. and D.I. Nwankwo, 2003. The impact of land based pollution on the hydrochemistry and macrobenthic community of a tropical West African creek. Proceeding of 7 th International Specialised Conferene on Diffuse Pollution and Basin Manag, 2003, Dublin, Ireland, pp: 1-16.

Cole, H.A., 1977. Sand and gravel extraction. Marine Polut. Bull., 8: 193-240.

Dance, K.W. and H.B.N. Hynes, 1980. Some effects of agricultural land use on stream insect communities. Environ. Pollut. Ser. A. Ecol. Biol., 22: 19-28.

Diaz, R.J., M. Solan and R.M. Valente, 2004. A review of approaches for classifying benthic habitats and evaluating habitat quality. J. Environ. Manage., 73: 165-181.

Dillon Jr, R. T., 2000. The Ecology of Feshwater Molluscs. Cambridge University Press, Cambridge, UK.

Edema, C.U., J.O. Ayeni and A. Aruoture, 2002. Some observations on the zooplankton and macrobenthos of the Okhuo River, Nigeria. J. Aqua. Sci., 17: 145-149.

Edmunds, J., 1978. Sea Shells and other Molluscs found on West African Coast and Estuaries. Ghana University Press, Accra, pp: 146.

Edokpayi, C.A., J.C. Okenyi, A.E. Ogbeibu and E.C. Osimen, 2000. The effect of human activities on the macrobenthic invertebrates of Ibiekuma Stream, Ekpoma, Nigeria. Biosci. Res. Commun., 12: 79-87.

Egborge, A.B.M., L.I. Ezemonye and G.E. Awoze, 2003. Macroinvertebrate fauna of Udu-Ughievwen Wetlands, Southern, Nigeria. J. Aqua. Sci., 18: 1-8.

Egonmwan, R.I., 2008. The ecology and habits of Tympanotonus fuscatus var. radula (L.) (Prosobranchia: Potamididae). J. Boil. Sci., 8: 186-190.

Emere, M.C. and C.E. Nasiru, 2007. Macroinvertebrate as indicators of the water quality of an urbanised Stream, Kaduna, Nigeria. Medwell J. Fish. Int, 2: $152-157$. 
George, A.D.I., J.F.N. Abowei and E.R. Daka, 2009. Benthic macroinvertebrate fauna and physic-chemical parameters in okpoka creek sediments, Niger Delta, Nigeria. Int. J. Anim. Vet. Adv., 1: 59-65.

Holme, N.A. and A.D. McIntyre, 1984. Methods for the Study of Marine Benthos. 2nd Edn., Blackwell Scientific Publications, Oxford, London, Edinburgh, pp: 387.

Ikomi, R.B., F.O. Arimoro and O.K. Odihirin, 2005. Composition, distribution and abundance of macroinvetebrates of the upper reaches of River Ethiope, Delta State, Nigeria. The Zoologist, 3: 68-81.

Lloyd, M. and R.G. Ghellardi, 1964. A table for calculating the equitability components of species diversity. J. Anim. Ecol., 33: 217-225.

Lydeard, C., R.H. Cowie, W.F. Ponder, A.E. Bogan and P. Bouchet, 2004. The global decline of nonmarine mollusks. Bioscience, 54: 321-330.

Macan, T.T., 1959. A Guide to Freshwater Invertebrate Animals. Longman Group Ltd., Englands.

Mackie, G.L., 1998. Applied Aquatic Ecosystem Concepts. University of Guelph Custom Coursepack, 12 Chapters, Index, Canada.
Odum, E.P., 1971. Fundamentals of Ecology. 3rd Edn., W.B. Saunders Company, Philadelphia, pp: 574.

Oyenakan, J.A., 1979. The ecology of the genus Pachymelania in Lagos lagoon. Arch. Hydrobiol., 86: 515-522.

Pennak, R.W., 1978. Freshwater Invertebrates of the United States. 2nd Edn., John Wiley and Sons, USA., pp: 803 .

Rosenberg, D.M. and V.H. Resh, 1993. Freshwater Biomonitoring and Benthic Invertebrate. Chapman and Hall, New York.

Shannon, C.E. and W. Weaver, 1963. The Mathematical Theory of Communications. University of Illinois Press, Urbana, pp: 125.

Sikoki, F.D. and N. Zabbey, 2006. Environmental gradients and Benthic community of the middle reaches of Imo River, South-Eastern Nigeria. Environ. Ecol., 24: $32-36$.

WHO, 1978. A Field Guide to African Freshwater Snails. WHO Snail Identification Center, Danish Bilharziasis Lab. Jaegersborg, Charlottenlund Denmark, pp: 30.

Woolhouse, M.E. and S.K.Chandiwana, 1990. Population dynamics model for Bulinus globosus, intermediate host for Schistosoma haematobium, in river habitats. Acta Trop., 47: 151-160. 